\title{
이음향방사
}

성균관대학교 의과대학 삼성서울병원 이비인후과학교실

$$
\text { 홍 성 화 }
$$

\section{Otoacoustic Emissions}

\author{
Sung Hwa Hong, MD \\ Department of Otorhinolaryngology-Head and Neck Surgery, Sungkyunkwan University School of Medicine, \\ Samsung Medical Center, Seoul, Korea
}

\section{서 론}

이음향방사는 1978 년 $\mathrm{Kemp}^{1)}$ 에 의해 처음 발견된 이 후 청각 기관의 생리적 작용에 대한 많은 이해를 가능 하게 하였고 임상적으로는 청각 기능에 대한 비침습적 이며 객관적인 검사로 널리 이용되고 있다. 이음향방사 는 와우에서 발생되어 중이를 거쳐 외이도로 전달된 소 리에너지로 이는 외유모세포의 능동적 증폭작용 (active amplification process)의 부산물(by-product)로 이해 되고 있다.

이음향방사는 크게 자발 이음향방사(spontaneous otoacoustic emissions, SOAEs) 와 유발 이음향방사(evoked otoacoustic emissions)로 나눌 수 있는데 자발 이 음향방사는 외부 자극음이 없는 상황에서 와우에서 생 성, 중이를 거쳐 외이도로 방사되어 감지되는 소리에너 지이며, 유발 이음향방사는 외이에 가해진 음자극에 의 해 와우에서 생성되는 소리에너지이다. 유발 이음향방사 는 클릭과 같은 짧은 자극 후에 나타나는 일과성 유발 이음향방사(transient evoked otoacoustic emissions, TEOAEs) 와 순음을 주었을 때 측정되는 주파수 반응 이음향방사(stimulus frequency otoacoustic emissions,

교신저자 : 홍성화, 135-710 서울 강남구 일원동 50번지 성균관대학교 의과대학 삼성서울병원 이비인후과학교실 전화 : (02) 3410-3579 · 전송 : (02) 3410-3879 E-mail :hongsh@skku.edu
SFOAEs), 두 가지 순음을 주었을 때 이 들 주파수의 조 합음을 만들어 내는 변조 이음향방사(distortion product otoacoustic emissions, DPOAEs) 가 있다.

\section{자발 이음향방사}

자발 이음향방사(SOAEs)는 음자극이 없는 상황에서 와우에서 만들어지는 순음과 유사한 특성을 가진 음향 방사를 말한다. $\mathrm{SOAE}$ 의 측정을 위해서는 소리자극이 필요 없으므로, 마이크로폰만 있어도 가능하다. $\mathrm{SOAE}$ 의 효과적인 기록을 위해서는 마이크로폰의 높은 감도, 낮은 기본 소음수준을 가져야 하며, 가능한 측정하는 체 적이 작은 것이 유리하다.

SOAE의 발현률에 대하여 초기 연구에서는 35 40\% 정도로 보고하였으나 마이크로폰의 감도와 소음을 억제 하는 기술이 발전함에 따라 최근에는 정상 청력을 가진 사 람의 약 $72 \%$ 에서 발견된다고 한다. ${ }^{2)}{ }^{3)}$ 다수의 SOAE 가 일측 귀에서 나타나기도 하는데, 평균 4 개 정도가 존 재하며 ${ }^{3) 4}$ 한 사람의 양측 귀에서 주파수가 같지 않은 경우도 흔하다고 한다. ${ }^{5}$

$\mathrm{SOAE}$ 의 발현률은 남자보다 여자에서 약 2 배 높으며, 여자에서 다수의 SOAE가 발현되는 경향이 있다고 한 다. $^{5-7)}$ 또한 $\mathrm{SOAE}$ 는 좌측보다 우측 귀에서 더 발현률 이 높다고 한다. ${ }^{25)}$ 그러나, 이러한 차이의 원인은 아직 밝혀지지 않았다.

$\mathrm{SOAE}$ 의 발현은 신생아나 성인에서 차이가 없는 것으 
로 알려져 있으명-11) 미숙아에서도 비슷한 발현을 보 인다고 한다. ${ }^{8)}$ 60세 이상이 되면 정상 청력역치를 보여 도 SOAE의 발현률은 감소한다고 하며, ${ }^{12) 13)}$ 이와는 대 조적으로 유발 이음향방사는 연령이 증가하여도 청력역 치가 정상이면 발현률은 차이가 없다고 한다. ${ }^{14)}$

측정 시기에 따라 SOAE의 진폭은 다소 변할 수 있 으나 방사되어 나오는 주파수는 거의 일정한 특성을 가 지고 있다. 이는 아마도 기저막의 특이한 위치에서 $\mathrm{SOAE}$ 가 발생하기 때문이라고 해석한다. ${ }^{6)}$ 성인에서 $1 \sim 2 \mathrm{kHz}$ 에서 가장 흔히 $\mathrm{SOAE}$ 가 측정되는데 이러한 현상은 중 이의 공명 특성이 반영된 것으로 생각된다. 전형적인 경우는 0.5 6 kHz 사이에 존재하며, 유아나 신생아는 성인보다 약간 높은 주파수 $(3 \sim 4 \mathrm{kHz})$ 를 보인다. ${ }^{9-11)}$ $\mathrm{SOAE}$ 의 크기는 $-12 \sim 20 \mathrm{dBSPL}$ 이며 성인에서는 평균 $-3 \sim 0 \mathrm{dBSPL}$ 이다. ${ }^{2) 9)}$ 유아에서는 성인보다 약간 커서 $10 \mathrm{dBSPL}$ 정도라고 한다. ${ }^{910)} \mathrm{SOAE}$ 의 발현은 외부적 인 요소에 의해 영향을 받을 수 있으며, 이에는 외부에 서의 음자극, 온도변화, 약물 등이 있다.

$\mathrm{SOAE}$ 가 귀에서 자발적으로 나오는 소리라는 점에서 이명과 비슷한 기전을 가지고 있는 것이 아닌가 하여 이명과의 연관성에 대한 연구는 비교적 활발히 진행되 어 왔다. 현재까지의 연구 결과로 $\mathrm{SOAE}$ 와 이명의 관계 는 명확하지 않으며, SOAE와 이명의 주파수는 일치하 지 않는다. 정상 청력 군에서는 SOAE가 이명의 원인이 될 수 있으나 이명환자 전체를 놓고 보았을 때는 이것 이 원인이 되는 부분은 미미하다고 한다. 다른 연구자료 에 의하면 이명이 있는 환자 전체의 $4 \%$ 에서 SOAE가 그 원인이었다. ${ }^{15)}$ 최근에 이명 환자가 대조군에 비해 $\mathrm{DPOAE}$ 가 감소되어 있다는 보고도 있다. ${ }^{16) 17)}$

\section{주파수 반응 이음향방사}

Kemp와 Chum에 의해 1980년에 처음으로 낮은 강 도의 계속적인 순음을 주면 자극 주파수 대역에 추가적 인 음압이 와우에서 생성됨을 보고하였고 이를 주파수 반응 이음향방사(SFOAEs) 로 명명하였다. ${ }^{18)}$ 기록을 위 해 사용되는 음향 프로브와 마이크로폰은 일과성 유발 이음향방사의 장치와 유사하다. 외이도 내에서의 자극음 크기는 좁은 주파수 대역 통과 필터를 통과시킨 후 측
정한다. $\mathrm{SFOAE}$ 에서는 자극음과 음향방사가 동일한 주 파수를 가지기 때문에 자극음과 방사음을 구별하는데 있어 기술적인 어려움이 있기 때문에 임상적으로나 연 구 목적으로 많이 사용되지는 않으며 난청이 있는 경우 에는 어떤 소견을 보이는지 잘 알려져 있지 않다.

\section{일과성 유발 이음향방사}

1978년 Kemp가 처음 기술한 TEOAE는 귀에 클릭음, tone burst, 또는 tone pip과 같은 일과성 음(transient sound) 을 주면 나타나는 이음향방사를 말한다. ${ }^{1)}$ 자극 음 중 클릭음은 짧은 시간 안에 넓은 음역의 주파수부 위를 검사하기 위하여 사용되며 이상적으로는 $0.3 \mathrm{kHz}$ 와 $8 \mathrm{kHz}$ 사이의 주파수를 일정하게 포함하는 음역을 자극하고 기록할 수 있어야 한다. 짧은 자극 폭을 가지고 있는 tone burst도 좁은 부위의 주파수대를 평가하는데 사용된다. TEOAE를 측정하기 위해서는 클릭음 또는 tone burst를 줄 수 있는 음원과 반응을 측정할 수 있는 민감 한 마이크로폰이 필요하며 깨끗한 $\mathrm{TEOAE}$ 를 측정하기 위 해서는 자극음에 의해 생기는 가공물(artifact)를 제거하여 야 한다(Fig. 1).

현재 가장 일반적으로 사용되는 가공물 제거 방법은 비 선형 감별법(non-linear differential technique)이다. 자극을 줄 때 네 개의 음자극을 사용하되, 처음 세 개는 같은 극성의 적은 진폭의 음을 사용하고, 네 번째는 반대 되는 극성으로 진폭이 3 배 큰 음을 사용한다. 나중에 각 각 네 개의 자극에 의한 반응을 평균 가산하면 자극음과 외이의 울림 등의 가공물이 상쇄된다. 이와 함께 각 세 트의 자극을 두개의 버퍼에 저장하여 동시에 혹은 차례 로 평균 가산하여 두개의 파형을 얻어 이를 비교함으로써 재현성(reproducibility)을 확인한다. 이 외에도 반응강도

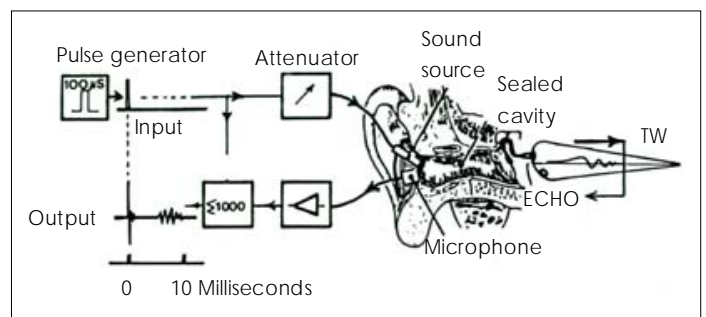

Fig. 1. Typic al rec ording schematic for TEOAES. 
를 표현하는 지표로는 서로 독립적인 것은 아니지만 평균 방사반응의 상대적 강도, 주변소음(background noise) 의 평가, 소음과 음향방사의 비교 등이 있다.

$\mathrm{TEOAE}$ 가 있는지를 판단하는 기준은 일단 비선형적으 로 높은 자극음에서 포화되는 성질을 보이는 파형의 확 인이 필요하며, 두번째는 FFT상 뚜렷하게 돌출된 주파 수 특이적인 첨부를 보이면서 높은 상호연관성 혹은 재 현률을 보여야 한다. TEOAE 반응 양성의 기준은 1991년 Kansas symposium에서 echo response $8 \mathrm{~dB}$, 재현율 (reproducibility) $50 \%$ 이상을 기준으로 하였으나 이 문 제에 관한 일치된 결론은 아직 없고 대개는 $5 \mathrm{~dB}, 50 \%$ 의 기준을 사용한다.

Fig. 2는 정상인에서 측정한 일과성 유발 이음향방사 의 결과이다. 반응의 분석구간을 2.5 20 msec로 설정 하여 측정한다(Fig. 2의 아래 경계선의 굵은 선). 자극음 의 평균가산은 보통 260회를 한다. 자극음의 상태를 판 단하는 데는 안정성(stability), 시간 축에서의 파형(temporal waveform), 스펙트럼(spectrum) 등 3개의 매개 변수를 이용한다. 안정성은 260 개의 클릭음의 시작과 끝 의 일치 정도의 인덱스로 $90 \%$ 이상이 되어야 바람직하 다. 그림에서 자극음은 $80.4 \mathrm{~dB}$ 의 peak sound pressure level(pSPL)을 보이며 그 안정성이 97\%임을 보이고 있다. 방사음은 평균 $15.6 \mathrm{~dB}$ 의 강도를 보이며, $0 \sim 6 \mathrm{kHz}$ 사이의 전반적인 재현률(reproducibility)은 $98 \%, 1,2$, $3 \mathrm{kHz}$ 에서는 $94 \%$ 이상을 보여 반응의 안정성을 보이 고 있다.

프로브가 얼마나 외이도에 잘 맞느냐는 TEOAE 뿐 아니라 모든 이음향방사의 측정에 가장 중요한 요소이 다. 좋은 반응과 주파수 대역을 얻기 위해서 가능한 프

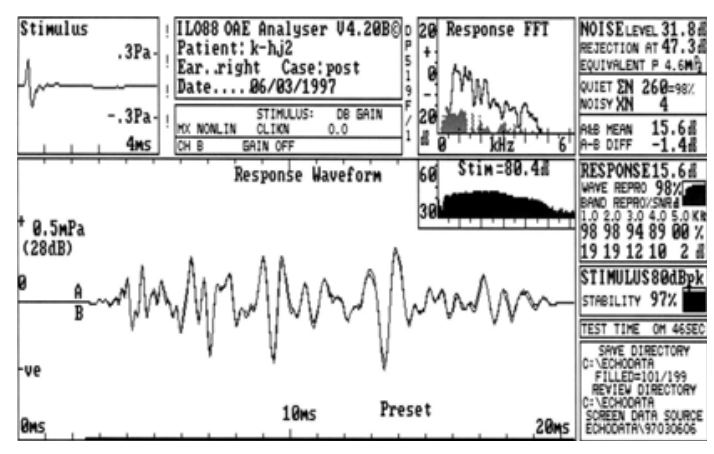

Fig. 2. Nomal a dult TEOAEs. 로브(probe)의 끝에 트랜스듀서(transducer) 가 위치하 여야 한다. 이는 $3 \mathrm{kHz}$ 이상의 고주파수의 이음향방사 를 측정하고 자극음에 의한 잡음의 제거를 위해 중요하 다. 프로브는 신생아를 위한 작은 크기와 일반용의 큰 크 기가 있다. 일반적으로 구경이 큰 경우가 보다 넓은 반응 주파수를 받아들일 수 있으며, 신생아와 같이 큰 구경이 이용 불가능한 경우를 제외하고는 대개 큰 구경의 프로 브를 사용한다. 이음향방사의 기록을 위해서는 프로브가 외이도의 중심에 있어야 하고 소리가 새지 않도록 잘 맞아야 한다. 대개 임피던스 청력검사를 할 때와 같이 적당한 크기의 고무 팁을 프로브에 끼어 고무 팁의 날 개 부분이 프로브와 외이도 사이를 완전히 밀봉할 수 있어야 한다. 그렇지 못한 경우는 잡음이 많이 들어오며, 소리 자극을 주는 트랜스미터나 프로브가 고막을 정면 으로 향해야 한다. 고무 팁이나 외이도의 벽으로 방해 받 지 않도록 위치하여야 한다.

Fig. 3은 프로브와 트랜스듀서의 위치에 따라 각각 다 른 반응이 나올 수 있음을 보여준다. 클릭음의 자극시 짧 고 일과성의 자극이 주어지며 파형의 변화가 적어야 한 다. 그리고 파워 스펙트럼 상 $1 \sim 5 \mathrm{kHz}$ 의 범위에 있다. Fig. $3 \mathrm{~A}$ 는 두 개의 버퍼에서 얻은 파형이 잘 일치하는 소견을 보이고 이음향방사의 파워 스펙트럼 상 잡음 수 준보다 뚜렷하게 높은 cross-power 스펙트럼이 보인 다. Fig. $3 \mathrm{~B}$ 는 피팅이 제대로 되지 못한 경우로 공기의 밀폐가 이루어지지 않은 경우다. 외이도의 울림으로 긴 자극음의 파형이 만들어지고, 자극음의 스펙트럼 상 1 $\mathrm{kHz}$ 이하의 음은 새나가서 음압이 거의 없고, $2 \mathrm{kHz}$ 주 위에서 높은 음압을 보이며, $4 \mathrm{kHz}$ 에서 고랑을 이룬다. 외부의 잡음이 들어가므로 유발 이음향방사가 전혀 기 록되지 못한다. 두개의 파형이 전혀 일치하지 않으며, 이 음향방사의 파워 스펙트럼 상 잡음만 보인다. 경우에 따 라서는 외이도가 너무 넓어서 피팅이 잘 되었음에도 불 구하고 외이도의 울림이 있는 경우가 있는데 이 경우는 자극음의 파워 스펙트럼 상 $1 \mathrm{kHz}$ 이하의 주파수에서 도 음압이 나온다. 일반적으로 Fig. 3B와 같이 자극음의 스펙트럼 상 첨부와 고랑이 있는 경우는 피팅을 다시 해 서 검사하여야 한다. Fig. $3 \mathrm{C}$ 는 팁이 너무 긴 경우이다. 이 경우에는 특히 고주파수 영역의 외이도 울림이 만들 어진다. 마이크로폰과 트랜스미터가 가깝게 위치하는 경 


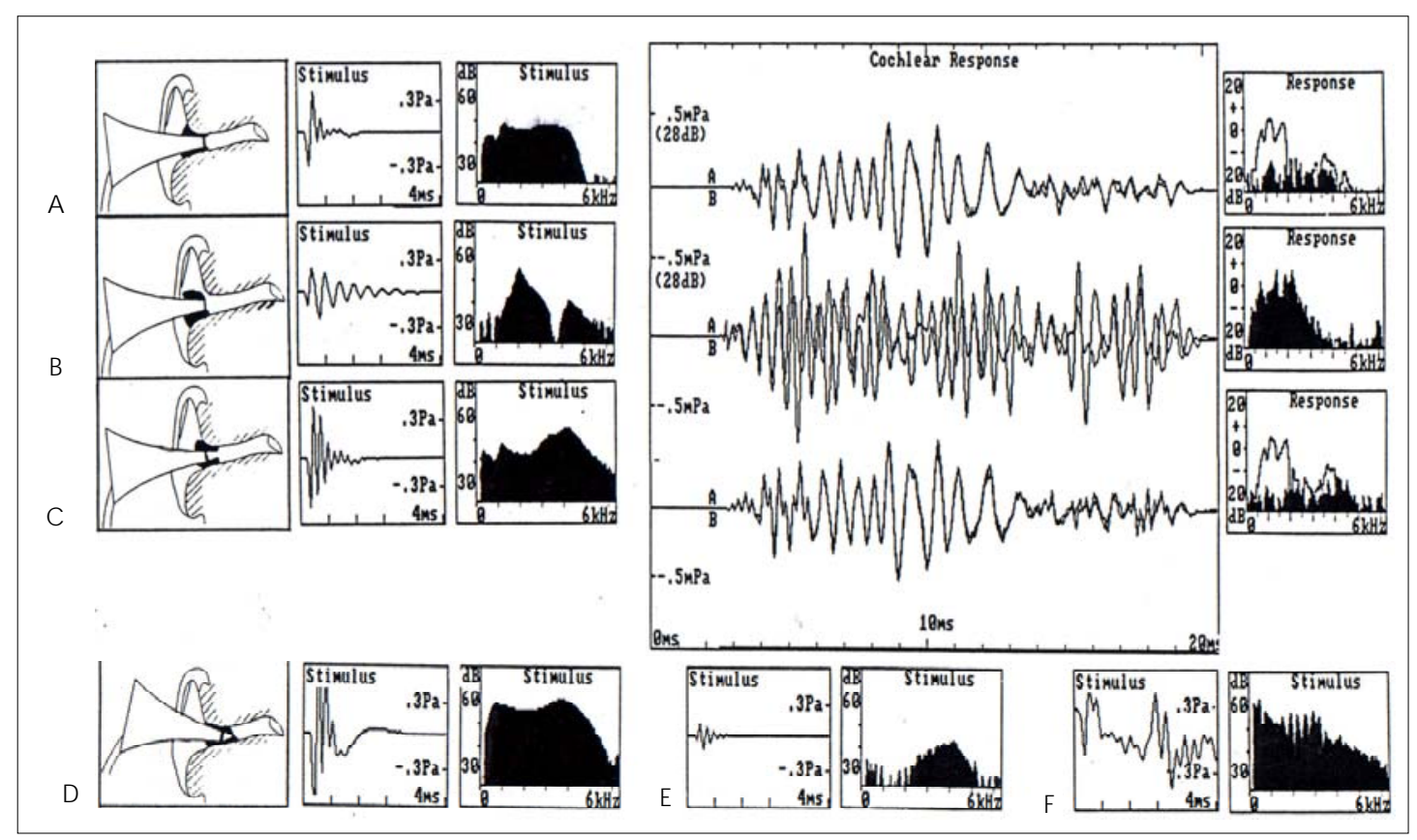

Fig. 3. Differences of $O A E$ responses by variation of probe fitting.

우 고무 팁이 프로브의 끝보다 앞으로 나오게 되면 고 무 팁의 공간에서 고주파수의 외이도 울림이 나타난다. 그림에서는 자극음의 파형이 조금 길어져 외이도 울림이 나타남을 알 수 있고, 파워 스펙트럼 상 $4 \mathrm{kHz}$ 주위에 음압이 커져있음을 보이나, $1 \mathrm{kHz}$ 의 음압은 정상이므로 피팅이 새는 것은 아님을 알 수 있다. 이음향방사의 기록 은 가능하나, 음압이 강조된 $4 \mathrm{kHz}$ 주위에서는 길게 이 어지는 고주파의 외이도 울림이 실제 이음향방사와 구 별이 힘든 경우가 있으므로 이와 같은 자극음의 공명이 있는 경우는 주의를 요한다. Fig. $3 \mathrm{D}$ 는 잘못된 삽입 각 도로 고무 팁이 프로브를 막은 경우로 자극음의 파형이 비정상적으로 크고, 저주파수의 여운이 남는다. 자극음 의 파워 스펙트럼도 비정상적으로 크게 나타나나 이음 향방사의 측정은 불가능하다. Fig. $3 \mathrm{E}$ 는 프로브가 빠진 경우로 자극음이 매우 작다. Fig. $3 \mathrm{~F}$ 는 피팅이 잘 되었 으나 환자가 기침 등으로 소음을 유발하는 경우이다. 이 런 여러 가지 소견으로 검사 시 프로브의 위치와 피팅 의 적합성을 판단하고 검사를 시행하여야 옳은 결과를 얻을 수 있다.

임상적으로는 $\mathrm{TEOAE}$ 가 측정되지 않는 경우가 종종
발생하는데 이 경우 외이도 혹은 중이의 해부학적 이상 이나 장비의 문제, 또한 지나친 소음 등이 그 원인으로 생각되므로 이런 것들에 대한 평가를 하여야 한다. TEOAE는 나이에 따른 차이가 크지 않다고 알려져 있 으나 60 세 이상에서는 발현률이 $35 \%$ 로 떨어진다는 보 고가 있으며 이는 이 노인성 난청에 의한 청력감소에 의한 현상으로 생각되고 있다. 유발이음향방사도 대개 0.5 에서 $4 \mathrm{kHz}$ 범위 내의 일정 주파수에서 잘 나타나 는데 이는 기저막의 특정한 장소에서 이음향방사가 만들 어지기 때문이라고 생각한다. 클릭음에서는 이음향방사 가 없으나 tone burst를 사용한 경우 $20 \%$ 가량에서 해 당하는 주파수 대역에서 이음향방사가 관찰되기도 한다. 이음향방사 반응의 역치와 순음청력검사의 역치는 일치 하지 않는다. 그러나 $\mathrm{TEOAE}$ 는 정상 청력을 가진 경우 는 나이와 성별에 상관없이 거의 모든 경우에 측정이 가 능하며 동일한 피검자에 있어서 반응의 양상은 시간의 변화에 관계없이 비교적 일정하다. 특히 소아나 영유아 의 검사 시 문제가 되는 것이 삼출성 중이염이나 중이압 의 이상이 있는 경우이다. 중이의 압력이 맞지 않는 경우 는 $2 \mathrm{kHz}$ 이하의 저음에서 이음향방사의 음압이 감소하 
고, $3 \mathrm{kHz}$ 이상에서는 강조되는 효과를 보인다. 삼출성 중이염이 있는 경우는 이음향방사의 측정이 불가하므로 신생아에서 이음향방사가 없는 경우에는 이경검사와 임 피던스 검사를 시행하여 중이염 여부를 확인해야 한다.

청력의 감소가 15 35 dB이 넘는 경우는 TEOAE가 나타나지 않는다. 대개 순음청력검사에서 정상인 경우는 클릭음으로 자극을 준 경우, 대개의 주파수 영역에서 이 음향방사가 기록된다. 일반적으로 $\mathrm{TEOAE}$ 는 $1 \mathrm{kHz}$ 에 서는 $40 \mathrm{~dB}$ 이상, $0.5,1,2,4 \mathrm{kHz}$ 에서는 $35 \mathrm{~dB}$ 이상 의 청력소실이 있으면 나타나지 않는다고 생각하고 있다. 따라서 일반적으로 $\mathrm{TEOAE}$ 가 측정이 가능한 경우는 적 어도 해당 주파수에서는 $30 \mathrm{~dB} \mathrm{HL}$ 정도의 청력 역치를 가진다고 생각할 수 있다. 그리고 정상 청력을 보이는 주 파수 대역은 TEOAE의 스펙트럼 분석을 통해서 알 수 있으며, 이음향방사 파형의 주파수분석을 해 보면 1 4 $\mathrm{kHz}$ 의 broad band noise가 나타나고 그 위에 방사음의 multiple narrow band peak가 나타난다. 가장 높은 peak 는 주로 1 2 kHz 에서 발견되고 자극음이 커지면 비선 형적 형태로 방사음도 커지며 인접주파수대로 확대된다. 따라서 1 2 $\mathrm{kHz}$ 사이의 청력이 TEOAE를 유발하는데 가장 중요하다. 클릭음으로 유발된 이음향방사를 가지고 $\mathrm{TEOAE}$ 의 스펙트럼에 포함되지 않은 주파수 대역의 청 력역치에 대한 추정은 불가능하다. 따라서 저자에 따라 서는 클릭음보다는 주파수 특이적인 tone-burst를 이용 하는 것이 도움이 된다고 생각하고 있다. 이 경우 클릭 음에 비해 각각의 주파수 대의 자극음을 따로 써야 하므 로 시간적으로 단순한 선별검사를 위해서라면 이득이 없 다. Tone burst의 장점은 트랜스듀서의 한계에 도달하 지 않고, 와우의 특정한 지점에 높은 수준의 소리자극을 가할 수 있다는 것이며, 따라서 클릭음으로는 정확히 이 음향방사가 측정되지 않는 주파수 대역에서도 tone burst 로는 측정이 가능한 경우가 있다.

\section{변조 이음향방사}

와우에서 나타나는 여러 가지 비선형 특성(non-linearity)중 하나인 변조 산물(distortion product)로 1979 년 Kemp에 의해 사람에서 측정되었다. ${ }^{19)}$ 변조 산물은 두 가지 순음을 주었을 때 각 순음의 정배수가 아닌 주파
수를 와우에서 발생하는 것을 말한다. 즉, 자극을 위해 사용하는 기본음을 낮은 주파수의 자극음부터 각각 $\mathrm{f} 1$, $\mathrm{f} 2$ 이라고 하며 두 가지의 소리를 주었을 때 와우에서 $\mathrm{f} 1$, f2에 대한 정배수 주파수를 가진 조화음(harmonics, mf1 또는 nf2) 이외에 $\mathrm{mf} 1 \pm \mathrm{nf} 2$ 식의 주파수를 가진 소리 를 만들어 낼 수 있다는 것이다. 이런 여러 개의 변조 산 물 중 2f1-f2의 주파수에서 가장 큰 반응을 갖기 때문 에 $\mathrm{DPOAE}$ 의 특성을 이 주파수 영역의 반응 특성으로 파악하게 된다. $\left.{ }^{20)} 21\right)$

Fig. 4는 $\mathrm{DPOAE}$ 를 측정하기 위해서 필요한 시스템 으로 대개의 경우 두 개의 독립된 스피커를 통한 두 개의 마이크로폰과 이어폰이 부착된 프로브, 자극을 만드는 시스템, 소리의 증폭기, 평균가산을 위한 시스템 등으로 구성되어 있다.

2f1-f2의 변조 산물의 진폭은 5 15 dBSPL이며 자 극하는 순음의 상대적, 절대적 강도와 주파수의 비율에 영향을 받는다. 두 순음의 주파수 비율이 작을 때 즉 $\mathrm{f} 2 /$ $\mathrm{f1}$ 이 작을 때 변조 산물이 더 크게 나타나며 일반적으로 $\mathrm{DPOAE}$ 는 $\mathrm{f} 1 / \mathrm{f} 2$ 비가 1.21 1.22이고 L1 (낮은 주파수 성분의 음압)이 L2(높은 주파수 성분의 음압) 보다 0에 서 $15 \mathrm{~dB}$ 정도 강할 때 잘 기록된다고 알려져 있다. ${ }^{22) 23)}$ 입/출력 함수는 같은 크기의 자극음을 사용하는 경우는 자극음의 크기가 60 70 dB이 될 때까지는 선형적으로 거의 1 에 가까운 이득을 보이고, 그 이후에는 포화된다. $\mathrm{DPOAE}$ 는 $0.5 \sim 5 \mathrm{kHz}$ 사이에서는 거의 모든 정상인에 서 관찰이 가능하고 $1 \sim 2 \mathrm{kHz}$ 범위에서 가장 높은 발현 률을 보인다. $\mathrm{DPOAE}$ 의 정상인에서의 발현률이 정확히 알려져 있지는 않으나 대략 85 98\% 정도에서 관찰이 가능하다고 생각한다. $\mathrm{DPOAE}$ 는 $\mathrm{f} 1, \mathrm{f} 2$ 의 기하평균에 해

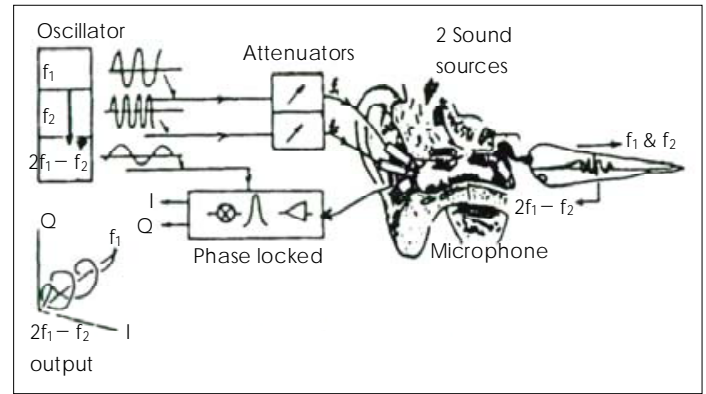

Fig. 4. Typic al recording schematic for DPOAEs. 
당하는 주파수를 담당하는 와우 기저막의 위치에서의 반 응을 반영한다는 이론과 f2에 해당하는 와우 기저막이 주 요 위치라는 이론이 있다. 자극음의 강도가 낮을 때는 $\mathrm{f} 2$ 에 가깝고 자극음이 커지면 두 순음의 기하평균에 해당하 는 부위에 가깝다고 알려져 있다. DPOAE 반응은 대개 중간주파수 (mid-frequency) 대에서 가장 강하다. 때로 는 $500 \mathrm{~Hz}$ 이하에서도 나타날 수 있지만 이러한 부분은 소음의 영향을 많이 받는다는 문제를 가지고 있다.

검사는 보통 2 3가지 paradigm을 사용할 수 있으며, $\mathrm{DPOAE}$ 청력도(audiogram), 잠복기 그래프(latency gram), 입/출력 함수곡선(input/output function)이 가 능하다. 2f1-f2의 DPOAE가 생성되는 기원은 두 개의 자극음의 주파수에 해당하는 해부학적 위치 사이이지 변 조 물의 주파수 위치가 아니며, 따라서 ILO88의 경우는 변조산물의 생성에 보다 중요한 $\mathrm{f} 2$ 를 기준으로 X축의 주 파수 성분을 표시하고 Virtual사의 기계에서는 f1과 f2 의 기하평균 $(\sqrt{f 1 \times f 2})$ 을 이용하여 X축을 표시한다.

Fig. 5 의 첫번째 그림은 순음자극의 강도를 일정하게 해 놓고 주파수를 변화시키는 DPOAE 청력도(audiogram)이다. 이 경우는 $\mathrm{L} 1=65 \mathrm{~dB}, \mathrm{~L} 2=50 \mathrm{~dB}$ SPL이 고 f2의 주파수를 기준으로 자극 주파수를 변화시킨다. 대 개 f2 주파수의 간격은 $1 / 2$ 혹은 $1 / 4$ 옥타브를 흔히 사 용한다. 바닥의 진한 색의 영역은 검사 중 해당 주파수의 영역의 소음 수준으로 이 경우에는 소음과 비교시 DPOAE 의 진폭이 얼마나 나오는지로 해석하게 된다. 두번째 그 림은 $\mathrm{DPOAE}$ 의 잠복기를 그래프로 그린 것으로 자극과 $\mathrm{DPOAE}$ 가 나타나는 시간차를 $\mathrm{msec}$ 의 단위로 표시하 며, 주파수가 증가할수록 $\mathrm{DPOAE}$ 의 발생 장소가 와우 기저부로 내려오므로 잠복기는 짧아진다. 이런 형태에 변화가 생기는 경우는 이음향방사의 크기가 충분치 않아 잠복기의 추정이 곤란한 경우이며, 와우의 $\mathrm{DPOAE}$ 생 성 위치에 이상이 있음을 시사한다. 이 방법은 많이 사용 되는 것은 아니나 사람에 따라 차이가 큰 $\mathrm{DPOAE}$ 의 진 폭을 이용한 DPOAE 청력도 보다는 해석할 때 에러를 줄일 수 있는 장점이 있으며, 기술적인 잡음을 배제하고 생물학적 신호임을 증명할 수 있는 장점이 있다. 세번째 그림은 입/출력 곡선(input/output function)이다. 이 경 우에는 f1, f2는 고정된 주파수를 사용하고, L1, L2를 일정 한 단계로 변화 시키면서 $\mathrm{DPOAE}$ 의 진폭을 측정한다.

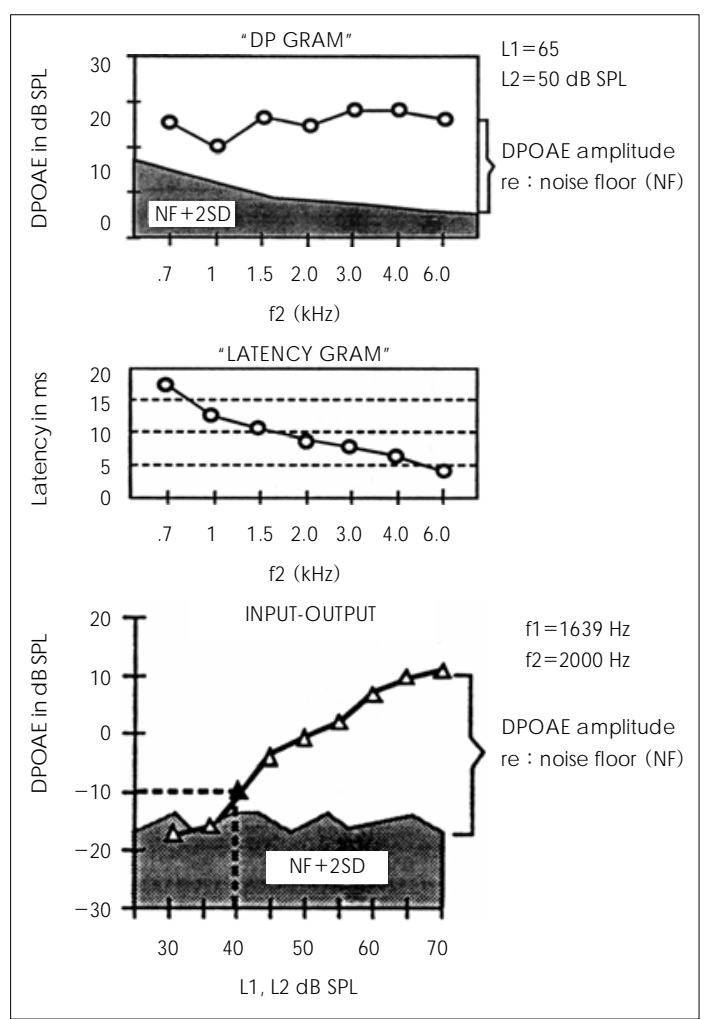

Fig. 5. DP-gram, latency-gram, and input-out function.

이 경우는 $\mathrm{DPOAE}$ 가 유발되는 자극강도의 범위를 표시할 수 있는 장점이 있다. 만약 낮은 음자극에서는 DPOAE가 측정이 되지 않고, 강한 음에서만 $\mathrm{DPOAE}$ 가 측정된다면 자극음으로 사용된 음의 주파수 대역에 해당하는 와우의 손상을 의심할 수 있다. 또한 $\mathrm{DPOAE}$ 의 진폭이 소음 수 준보다 커지는 자극음의 크기를 정하여 $\mathrm{DPOAE}$ 의 역치 로 표시할 수도 있다.

$\mathrm{TEOAE}$ 에서와 같이 $\mathrm{DPOAE}$ 도 정상 청력인에서는 잘 나타나며 신생아에서도 나타난다고 알려져 있다. 청력역 치가 $15 \mathrm{~dB}$ 를 넘지 않으면 $\mathrm{DPOAE}$ 는 항상 출현하고 역 치가 $50 \mathrm{~dB}$ 를 넘으면 발현하지 않는다. 이 중간영역에서 는 자극음의 강도가 증가하게 되면 $\mathrm{DPOAE}$ 가 양성 반 응을 보일 수 있다. $\mathrm{DPOAE}$ 는 0.5 에서 $8 \mathrm{kHz}$ 의 넓은 주 파수 범위에서 측정된다.

$\mathrm{DPOAE}$ 를 이용하여 신생아의 선별검사로 사용되고 있 으며 그 결과에 대해서 많은 논문이 발표되었다. DPOAE 를 이용하여 선별검사를 하는 경우 통과-탈락의 기준은 
$\mathrm{DPOAE}$ 청력도를 이용하는 경우와 입/출력곡선을 이용 하는 방법으로 크게 나눌 수 있다. DPOAE의 나이에 따 른 변화는 순음청력도 상에서 청력이 떨어지는 것보다 는 그 변화가 적게 나타난다. 특정 주파수에서의 순음청 력도 상의 청력역치가 나이에 따라 감소하는 기울기에 비해, 나이에 따른 $\mathrm{DPOAE}$ 의 역치 감소는 변화가 적으 며, 이는 노인성 난청이 외유모세포의 손상에 의한 것 보다는 혈관조(stria vascularis)의 위축과 같은 대사성 난청이 더 중요함을 보여주는 결과이다. ${ }^{24)}$

\section{이음향 방사의 임상적 적응}

이음향방사는 주관적 청력검사가 어려운 환자의 청력 에 대한 평가와 신생아청력선별검사, 감각신경성 난청의 감별진단, 이독성이나 소음에 의한 와우 상태의 추적 관 찰에 주로 이용되고 있으며, 최근에는 원심성 와우 경로 (cochlear-efferent system)에 대한 연구의 도구로 많 이 사용되고 있다.

이음향방사는 다른 임상 검사들과 다른 몇 가지 장점 을 가지며, 그 중의 하나가 객관적인 검사라는 사실이다. 이러한 검사의 객관성으로 인하여 이 검사는 일반적인 주 관적 청력검사로 평가가 어려운 소아(3세 이하), 이독성 약제를 투여받고 있는 중환자, 외국인, 복수장애자, 정신 이 혼미한 노인, 검사에 정직하게 반응하지 않는 사람 등 의 검사에 적절히 사용될 수 있다. 검사가 비침습적이며, 숙달되지 않은 사람도 쉽게 시행할 수 있다는 점도 장 점으로 간주된다. 또한 이음향방사의 검사기기는 컴퓨터 의 소프트웨어로 쉽게 장치되고 검사 결과가 정확하고 시행이 빠르고 비교적 저렴하다는 장점을 가지고 있다. 무엇보다 특이한 이음향방사의 장점은 이 검사가 외유모 세포 특이적인 객관적 검사라는 사실로 외유모세포의 문 제에 의해 발현되는 모든 청력장애에 민감하게 반응한 다는 사실일 것이다. 그러나 이음향방사도 아직은 해결 되어야 할 몇 가지 문제점들이 있는데, 검사결과가 피검 자의 내부 소음에 의한 영향을 많이 받으며, 다른 검사 에서와 같이 역치의 개념이 확실하지 않아 청력의 정확 한 평가가 어렵다는 점, 그리고 피검자간의 검사결과의 차이가 많다는 점(intersubject variability) 등이다.

$\mathrm{TEOAE}$ 를 검사함으로써 청력소실의 정도를 추정하는
것은 불가능하나 그 존재만 판단할 수 있다. 신생아의 이 음향방사는 성인에 비해 $10 \mathrm{~dB}$ 이상 큰 반응을 보이며, 이는 신생아에서 외이도의 용적이 작으므로 고막과 마 이크로폰 사이의 결합이 더 뛰어나서 생기는 현상으로 생 각되나 신생아에서는 이음향방사 자체가 더 클 가능성도 배재할 수는 없다. 또한 신생아에서는 $1 \sim 5 \mathrm{kHz}$ 의 범위 에서 모두 고른 반응이 나타나는 것과는 달리 성인에서 는 고주파 영역에서 반응의 음압이 적은 경우가 많으며, 때로 반응이 일어나지 않는 주파수대역이 있는 경우도 흔하다. 신생아에서의 자극음의 파워 스펙트럼은 $4 \mathrm{kHz}$ 주위에 음압이 증가된 소견과 함께 $1 \mathrm{kHz}$ 이하에서는 음 압의 손실이 보여 약간은 자극음이 새어나가는 소견을 보인다. 이는 외이도가 워낙 좁고, 아직 이개가 부드럽 고 탄력성이 떨어져 완전한 피팅이 되지 않기 때문이다. 신생아나 유아에서 성인과 유사한 정도의 TEOAE의 발현률이 보고되었고, 주된 주파수 성분이 약간 높은 것 을 제외하고는 성인과 거의 유사한 성질을 보이고 있어 선별검사의 좋은 방법으로 증명되었다. 신생아 고위험군 에서의 선별검사로서 $\mathrm{TEOAE}$ 의 결과와 $\mathrm{ABR}$ 은 비교적 좋은 상관관계를 보이며, 민감도는 거의 $100 \%$ 에 가깝고, 특이도는 확실히 밝혀져 있지는 않으나 $73 \%$ 에서 $83 \%$ 정도로 생각된다. 대개는 자동화된 특별한 잡음 배제 시 스템을 갖춘 기구로 $\mathrm{TEOAE}$ 를 짧은 시간에 측정하여 정상과 비정상을 확인하고, 비정상인 경우는 $\mathrm{ABR}$, 임피 던스 청력검사, 행동 청력검사 등을 시행하여 확인한다. 신생아나 소아에서 선별검사를 할 때는 청력에 이상이 없 는 경우 통과(pass), 이상이 의심되어 재검사 혹은 나이 에 따라 $\mathrm{ABR}$ 이나 PTA가 필요한 경우를 의뢰(refer) 라고 표시하지만 어떤 기준이 가장 적합한 지에 대해서는 아직 정립된 바가 없으며, 논문에 따라 혹은 기관에 따 라 서로 다른 기준을 사용하고 있다. 일반적으로는 재현 성 $50 \%$ 의 기준을 많이 사용하며 이외에도 Salamy 등 은 재현성이 5 개의 주파수 대역 중 최소 3 개 이상에서 $80 \%$ 이상이면 통과로 정의하였으며, ${ }^{25)} \mathrm{Welzl}-\mathrm{Muller}$ 와 Stephan은 재현성 $60 \%$ 이상과 이음향방사의 크기 $7 \mathrm{~dB}$ $\mathrm{SPL}$ 이상을 기준으로 판단하였다. ${ }^{26)}$ 또한 Smyth등은 신 생아에서 $\mathrm{TEOAE}$ 와 $\mathrm{ABR}$ 을 비교하여 재현성 $65 \%$ 이 상, 이음향방사 크기 $10 \mathrm{~dB}$ 이상을 기준으로 하였을 때, 전 체적으로 $83.3 \%$ 의 민감도와 $49.6 \%$ 의 특이도를 보였으 
며, 특히 신생아 중환자실의 38 41주의 신생아에서는 $100 \%$ 에 가까운 민감도를 보인다고 보고하였다. ${ }^{27)}$ 이렇 게 주로 재현성에 중심을 두는 기준에 비해 신호-잡음 비율(SNR)을 중심으로 통과와 실패를 정의하는 경우도 있으며, Kei 등은 2 3 kHz와 3 4 kHz사이의 주파수 대역에서 SNR이 $3 \mathrm{~dB}$ 이상이면 통과시켰다. ${ }^{28)}$ Driscoll 등은 6세 정도의 소아에서 $\mathrm{SNR} 1 \mathrm{~dB}$ 이상의 기준으로 선별한 검사와 PTA상 $0.5,1,2,4 \mathrm{kHz}$ 중 어느 하나라 도 $25 \mathrm{~dB} \mathrm{HL}$ 이상인 경우를 비교하여, $65 \%$ 의 민감도 (sensitivity, hit rate) 와 7\%의 위경고율(false alarm rate $=1$-specificity)를 보고하여, SNR만으로 판정 시 가장 유리하다고 보고한 바 있다. ${ }^{29)}$

신생아청력선별검사(Universal Newborn Hearing Screening, UNHS)의 도구로 유발이음향방사가 매우 보편적으로 사용되고 있다. 선별검사로서 유발이음향방사 는 1) 외이나 중이의 이상이 없는 모든 사람에서 검사가 가능하며, 2) 주파수 특이성이 있고 언어의 이해에 중요 한 넓은 주파수 범위에 대한 평가를 할 수 있고, 3) 40 $50 \mathrm{~dB}$ 이상의 청력손실이 있으면 유발이음향방사는 발 현되지 않고, 4) 청신경의 기능정도에 영향을 받지 않으 며, 5) 검사시간이 짧고 6) 선별검사 시 진정제 투여가 필 요없고, 7 ) 검사의 재현성이 좋다는 장점이 있다. 반면에 선별검사로서 유발이음향검사의 단점은 1) 역치에 대한 정보를 주지 못하므로 보청기 사용 여부에 대한 정보를 주 지 못하며 2) 청성뇌간반응보다 일시적인 전음성 난청 (삼출성 중이염 등)이 있는 경우 반응이 잘 나타나지 않으 며, 3) 청성뇌간반응과 비교하여 소음에 의해 영향을 심 하게 받으며, 4) 청신경 등 중추성 장애의 경우에도 이음 향방사가 발현될 수 있다는 점 등이다. UNHS의 검사 도 구로써 최근까지 여러 연구를 종합해보면 자동화청성뇌간 반응(automated auditory brainstem response, AABR) 이 TEOAE보다는 우월한 것으로 보인다. Vohr 등은 $\mathrm{AABR}, \mathrm{TEOAE}, \mathrm{TEOAE}$ 와 $\mathrm{AABR}$ 의 2단계 검사를 이 용한 세가지 방법의 의뢰율(referral rate)을 각각 $3.21 \%$, $6.49 \%, 4.67 \%$ 로 보고하였다. ${ }^{30)}$ Bailey 등도 $\mathrm{AABR}$ 이 $\mathrm{TEOAE}$ 에 비해 의뢰율, 즉 위양성율 (false-positive rate)이 낮다고 보고하였고, ${ }^{31)}$ Lemons 등은 AABR이 총 소요비용이 적으며 의뢰율이 낮고 검사자가 익숙해지기 쉽다고 하였다. ${ }^{32)}$ 그러나, 최근 소음을 감소시키는 새로
운 방법을 도입한 이음향방사 기기가 개발되고 있어 ${ }^{33-35)}$ 향후에는 $\mathrm{AABR}$ 에 근접하는 의뢰율을 보일 것으로 기 대되고 있다.

이음향방사는 감각신경성 난청이 있을 때 병변 부위의 감별에 유용하다. 예를 들면 갑상선기능저하증이 있는 신 생아에서 감각신경성 난청이 있으나 정상적인 TEOAE 반 응을 보이므로 외유모세포의 기능은 정상인 것으로 생 각되며, ${ }^{36)}$ 혈압이 낮은 환자에서 $\mathrm{DPOAE}$ 반응이 낮은 것은 저혈압이 외유모세포의 기능을 저하시키는 것을 의 미한다. ${ }^{37)}$ 소뇌교각종양이 있을 때 DPOAE가 나타나면 종양의 기원이 청신경이 아니라는 것을 알 수 있으며, ${ }^{38)}$ 청신경종을 감마나이프로 치료한 후 점진적인 청력 저 하는 와우에 조사된 방사선량과 비례하며 TEOAE를 측 정함으로써 알 수 있다고 한다. ${ }^{39)}$

청신경병증(auditory neuropathy)의 분야에서도 이 음향방사의 출현은 새로운 도약을 보였다. 비록 청신경 병증이 새로운 질병은 아니지만 많은 새로운 연구를 만 들어내어 이 병에 대한 보다 정확한 이해를 가능하게 하 였다. ${ }^{40-43)}$ 전형적인 청신경병증은 정상적인 이음향방사 를 보이나 비정상적인 청성뇌간반응, 소리에 대한 행동 적인 반응이 없거나 비정상적인 경우이다. 그러나 청신경 병증이 와우의 이상을 동반할 경우는 이음향방사도 나타 나지 않는 경우가 있다. 청신경병증에 합당한 청성뇌간 반응 결과는 모든 파형이 나타나지 않거나 파형간 잠복 기가 길어지는 것이다. 이들 환자에서는 청성뇌간유발반 응 검사에서 강한 와우음전기반응 (cochlear microphonics)을 보이기도 한다.

다양한 선천성 감각신경성 난청에서 청성뇌간반응과 같 이 이음향방사를 시행함으로써 병변 부위에 대한 선별검 사로써 이용될 수 있다. 예를 들면, DFNA11, DFNA2를 비롯한 몇몇 상염색체 우성 비증후군성 감각신경성 난청 에서 이음향방사가 발현되지 않는다고 한다. ${ }^{44-46)}$ 미토 콘드리아의 돌연변이에 의한 난청일 경우에는 청성뇌간 반응검사와 이음향방사가 모두 비정상으로 나타나므로 와 우와 상부 청각경로에 이상이 있음을 시사한다. ${ }^{47)}$ EngelYeger 등은 DPOAE를 이용하여 connexin 26 돌연변 이의 보인자(carrier)와 비보인자(noncarrier)를 구별할 수 있다고 하였으며 이는 외유모세포가 내유모세포, 청신 경과 뇌간 경로 보다 connexin 26 돌연변이에 더 취약 
하기 때문이라고 하였다. ${ }^{48)}{ }^{49)}$

이독성의 발생을 감시하는 용도로 유발 이음향방사의 큰 장점은 아미노글라이코사이드 항생제, cisplatin 등의 이독성 약제에의 노출에 의한 이독성의 조기진단에 유 용하다는 것으로 이음향방사의 측정이 내이의 외유모세 포의 비가역적인 병변 형성 이전에 이독성을 알리는 민 감한 지표로서 의의를 갖는다는 것이다. 이러한 목적에는 $\mathrm{DPOAE}, \mathrm{TEOAE}$ 가 모두 사용될 수 있으나 DPOAE가 더 넓은 주파수범위의 이상을 반영하고 특히 이독성이 처 음 발현되는 고주파수 영역의 변화에 대한 정보를 주파 수 특이적으로 줄 수 있다는 장점이 있어 선호된다. 이 외에도 소음성 난청에서 순음청력검사에서와 같이 일과 성 역치변동(temporary threshold shift)을 반영할 수 있고 환자가 검사를 정직하게 하는지 알 수 있는 것이 장점이다. 유발이음향방사는 노인성 난청환자에서 고음 역에서의 청력손실을 객관적으로 추적하여 와우의 활동 성의 감소를 확인할 수 있다. 또한 와우의 역동적인(dynamic) 상태를 잘 반영하기 때문에 메니에르병이 있을 때 글리세롤 혹은 요소 검사(glycerol or urea test)에 도 효과적으로 사용될 수 있다. ${ }^{50)}$

최근에는 와우의 원심성 경로(cochlear-efferent system)의 기능적인 상태를 평가하기 위해 이음향방사가 연 구되고 있다. 와우에 원심성 신경의 분포는 내측(medial) olivocochlear efferent (MOC) 와 외측(lateral) olivocochlear efferent(LOC) 가 존재하는 것으로 알려져 있는 데 현재까지는 주로 $\mathrm{MOC}$ 에 대하여 연구되어 있다. $\mathrm{MOC}$ 는 동측 반사(ipsilateral acoustic reflex)일 경우, 와우 가 소리에 의해 자극을 받으면 후복측 와우핵에 있는 interneuron을 통해 뇌간을 교차하여 반대측 $\mathrm{MOC}$ 신경 세포를 자극하게 되고, 다시 뇌간을 교차하는 olivocochlear bundle을 통하여 와우의 외유모세포에 이른다. 반 대측 반사(contralateral acoustic reflex)는 소리에 의 해 자극된 청신경이 후복측 와우핵에 있는 interneuron 을 자극하고, 이 신경은 뇌간을 교차하여 반대측 $\mathrm{MOC}$ 신 경을 자극하여 반대측 와우의 외유모세포에 이른다. $\mathrm{MOC}$ 반사는 이음향방사를 이용하여 확인할 수 있는데, 동측 이나 반대측 귀에 광대역의 소음을 주면 $\mathrm{MOC}$ 가 활성 화되어 외유모세포의 기능을 억제하여 와우의 증폭 기능 이 억제되면서 이음향방사가 감소된다. 동측 $\mathrm{MOC}$ 반사
는 기술적으로 측정하기가 어려우므로 주로 반대측 반사 를 측정하게 된다. 이러한 $\mathrm{MOC}$ 반사는 $\mathrm{SFOAE}, \mathrm{TEOAE}$, $\mathrm{DPOAE}$ 를 이용하여 측정할 수 있는데, 각 방법에 따라 장단점이 있다. TEOAE와 $\mathrm{DPOAE}$ 를 이용한 방법의 단 점은 반응을 유발하기 위해서는 동측에 큰 자극음을 주 어야 하는데 이는 동측 $\mathrm{MOC}$ 반사를 유발할 가능성이 높 다는 점이다. 또한 $\mathrm{MOC}$ 반사를 유발하기 위하여 음자 극을 주면 중이 근육의 수축을 유발하여 중이염의 임피 던스를 증가시킬 수 있는데, $65 \mathrm{~dB}$ 이상의 음에서 유발 될 수 있으므로 $60 \mathrm{~dB}$ 의 자극음을 사용하는 것이 좋다 고 한다. ${ }^{51)} \mathrm{MOC}$ 반사에 의해 이음향방사의 억제되는 정 도는 연구마다 다양하게 보고되고 있으나, $50 \mathrm{dBSL}$ 의 광대역 잡음을 주었을 때 TEOAE는 $3.7 \mathrm{~dB}, \mathrm{DPOAE}$ 는 0.5 2 $\mathrm{dB}$ 정도가 억제된다고 한다. ${ }^{52-55)} \mathrm{MOC}$ 반사 에 의한 이음향방사의 억제는 연령이 증가함에 따라 감 소한다고 한다. ${ }^{56)}$ Olivocochlear efferent에 대한 연구 는 아직 대부분 실험적이지만 추가적인 연구와 기술의 발달이 되고 있으므로 향후 와우와 상위 청각 경로의 기 능을 반영하는 좋은 검사로 기대된다.

\section{결 론}

이음향방사는 이신경학과 청각학 분야에서 광범위하 게 연구되어 임상적으로도 유용한 도구가 되었다. 와우 의 병변과 후미로성 병변의 감별, 신생아청력선별검사, 이독성이나 소음성 난청의 감시 등에 널리 사용되고 있 으며 와우의 원심성 경로의 기능에 대한 비침습적인 검사 로도 유용하다. 이음향방사는 향후 새로운 기술이 계속 개발되면서 임상적 적응의 범위가 더욱 넓어질 것으로 기 대된다.

중심 단어 : 이음향방사 · 외유모세포.

\section{REFERENCES}

1) Kemp DT. Stimulated acoustic emissions from within the human auditory system. J Acoust Soc Am 1978;64 (5):138691.

2) Penner MJ, Glotzbach L, Huang T. Spontaneous otoacoustic emissions: measurement and data. Hear Res 1993;68 (2): 229-37.

3) Talmadge CL, Long GR, Murphy WJ, Tubis A. New off-line method for detecting spontaneous otoacoustic emissions in 
human subjects. Hear Res 1993;71 (1-2):170-82.

4) Lonsbury-Martin BL, Harris FP, Stagner BB, Hawkins MD, Martin GK. Distortion product emissions in humans. II. Relations to acoustic immittance and stimulus frequency and spontaneous otoacoustic emissions in normally hearing subjects. Ann Otol Rhinol Laryngol Suppl 1990;147:15-29.

5) Bilger RC, Matthies ML, Hammel DR, Demorest ME. Genetic implications of gender differences in the prevalence of spontaneous otoacoustic emissions. J Speech Hear Res 1990; 33 (3):418-32.

6) Martin GK, Probst R, Lonsbury-Martin BL. Otoacoustic emissions in human ears: normative findings. Ear Hear 1990;11 (2):106-20.

7) Probst R, Coats AC, Martin GK, Lonsbury-Martin BL. Spontaneous, click-, and toneburst-evoked otoacoustic emissions from normal ears. Hear Res 1986;21 (3):261-75.

8) Bonfils P, Francois M, Avan P, Londero A, Trotoux J, Narcy P. Spontaneous and evoked otoacoustic emissions in preterm neonates. Laryngoscope 1992;102 (2):182-6.

9) Burns EM, Arehart KH, Campbell SL. Prevalence of spontaneous otoacoustic emissions in neonates. J Acoust Soc Am 1992;91 (3):1571-5.

10) Kok MR, van Zanten GA, Brocaar MP. Aspects of spontaneous otoacoustic emissions in healthy newborns. Hear Res 1993;69 (1-2):115-23.

11) Strickland EA, Burns EM, Tubis A. Incidence of spontaneous otoacoustic emissions in children and infants. J Acoust Soc Am 1985;78 (3):931-5.

12) Bonfils P. Spontaneous otoacoustic emissions: clinical interest. Laryngoscope 1989;99 (7 Pt 1):752-6.

13) Norton SJ, Mott JB, Champlin CA. Behavior of spontaneous otoacoustic emissions following intense ipsilateral acoustic stimulation. Hear Res 1989;38 (3):243-58.

14) Stover L, Norton SJ. The effects of aging on otoacoustic emissions. J Acoust Soc Am 1993;94 (5):2670-81.

15) Penner MJ. An estimate of the prevalence of tinnitus caused by spontaneous otoacoustic emissions. Arch Otolaryngol Head Neck Surg 1990;116 (4):418-23.

16) Ami M, Abdullah A, Awang MA, Liyab B, Saim L. Relation of distortion product otoacoustic emission with tinnitus. Laryngoscope 2008;118 (4):712-7.

17) Ozimek E, Wicher A, Szyfter W, Szymiec E. Distortion product otoacoustic emission (DPOAE) in tinnitus patients. $J$ Acoust Soc Am 2006;119 (1):527-38.

18) Kemp DT, Chum R. Properties of the generator of stimulated acoustic emissions. Hear Res 1980;2 (3-4):213-32.

19) Kemp DT. Evidence of mechanical nonlinearity and frequency selective wave amplification in the cochlea. Arch Otorhinolaryngol 1979;224 (1-2):37-45.

20) Brown AM, Kemp DT. Suppressibility of the 2f1-f2 stimulated acoustic emissions in gerbil and man. Hear Res 1984;13 (1):29-37.

21) Martin GK, Ohlms LA, Franklin DJ, Harris FP, LonsburyMartin BL. Distortion product emissions in humans. III. Influence of sensorineural hearing loss. Ann Otol Rhinol Laryngol Suppl 1990;147:30-42.

22) Gaskill SA, Brown AM. The behavior of the acoustic distortion product, 2f1-f2, from the human ear and its relation to auditory sensitivity. J Acoust Soc Am 1990;88 (2):821-39.

23) Harris FP, Lonsbury-Martin BL, Stagner BB, Coats AC, Martin GK. Acoustic distortion products in humans: systematic changes in amplitudes as a function of $f 2 / f 1$ ratio. $J$ Acoust Soc Am 1989;85 (1):220-9.

24) Gates GA, Mills D, Nam BH, D’Agostino R, Rubel EW. Effects of age on the distortion product otoacoustic emission growth functions. Hear Res 2002;163 (1-2):53-60.

25) Salamy A, Eldredge L, Sweetow R. Transient evoked otoacoustic emissions: feasibility in the nursery. Ear Hear 1996; $17(1): 42-8$.

26) Welzl-Muller K, Stephan K. Confirmation of transiently evoked otoacoustic emissions based on user-independent criteria. Audiology 1994;33 (1):28-36.

27) Smyth V, McPherson B, Kei J, Young J, Tudehope D, Maurer $\mathrm{M}$, et al. Otoacoustic emission criteria for neonatal hearing screening. Int J Pediatr Otorhinolaryngol 1999;48 (1): 9-15.

28) Kei J, McPherson B, Smyth V, Latham S, Loscher J. Transient evoked otoacoustic emissions in infants: effects of gender, ear asymmetry and activity status. Audiology 1997; 36 (2):61-71.

29) Driscoll C, Kei J, McPherson B. Outcomes of transient evoked otoacoustic emission testing in 6-year-old school children: a comparison with pure tone screening and tympanometry. Int J Pediatr Otorhinolaryngol 2001;57 (1): 67-76.

30) Vohr BR, Oh W, Stewart EJ, Bentkover JD, Gabbard S, Lemons J, et al. Comparison of costs and referral rates of 3 universal newborn hearing screening protocols. J Pediatr 2001;139 (2):238-44.

31) Bailey HD, Bower C, Krishnaswamy J, Coates HL. Newborn hearing screening in Western Australia. Med J Aust 2002;177 (4):180-5.

32) Lemons J, Fanaroff A, Stewart EJ, Bentkover JD, Murray G, Diefendorf A. Newborn hearing screening: costs of establishing a program. J Perinatol 2002;22 (2):120-4.

33) Grandori F, Sergi P, Pastorino G, Uloziene I, Calo G, Ravazzani $\mathrm{P}$, et al. Comparison of two methods of TEOAE recording in newborn hearing screening. Int J Audiol 2002;41 (5):267-70.

34) Muller P, Kompis M. Evaluation of a noise reduction system for the assessment of click-evoked otoacoustic emissions. $J$ Acoust Soc Am 2002;112 (1):164-71.

35) Pourbakht A, Sheykholeslami K, Kaga K. Distortion evoked otoacoustic emission using GSI 70 analyzer for neonatal screening. Int J Pediatr Otorhinolaryngol 2002;64 (3):217-23

36) Parazzini M, Ravazzani P, Medaglini S, Weber G, Fornara C, Tognola G, et al. Click-evoked otoacoustic emissions recorded from untreated congenital hypothyroid newborns. Hear Res 2002;166 (1-2):136-42.

37) Balatsouras DG, Korres S, Simaskos N, Kandiloros D, Ferekidis E, Economou C. Otoacoustic emissions in patients with hypotension. J Laryngol Otol 2003;117 (4):265-9.

38) Mobley SR, Odabasi O, Ahsan S, Martin G, Stagner B, Telischi FF. Distortion-product otoacoustic emissions in nonacoustic tumors of the cerebellopontine angle. Otolaryngol 
Head Neck Surg 2002;126 (2):115-20.

39) Ottaviani F, Neglia CB, Ventrella L, Giugni E, Motti E. Hearing loss and changes in transient evoked otoacoustic emissions after gamma knife radiosurgery for acoustic neurinomas. Arch Otolaryngol Head Neck Surg 2002;128 (11): 1308-12.

40) Berlin CI, Morlet T, Hood LJ. Auditory neuropathy/dyssynchrony: its diagnosis and management. Pediatr Clin North Am 2003;50 (2):331-40, vii-viii.

41) Kaga M, Kon K, Uno A, Horiguchi T, Yoneyama H, Inagaki M. Auditory perception in auditory neuropathy: clinical similarity with auditory verbal agnosia. Brain Dev 2002; 24 (3):197-202

42) Madden C, Rutter M, Hilbert L, Greinwald JH, Jr., Choo DI. Clinical and audiological features in auditory neuropathy. Arch Otolaryngol Head Neck Surg 2002;128 (9):1026-30.

43) Podwall A, Podwall D, Gordon TG, Lamendola P, Gold AP. Unilateral auditory neuropathy: case study. J Child Neurol 2002;17 (4):306-9.

44) Oeken J, Stumpf R, Bootz F. DPOAEs and vestibular function in different types of autosomal-dominant non-syndromal hearing impairment. Auris Nasus Larynx 2002;29 (1):29-34.

45) Stern RE, Lalwani AK. Audiologic evidence for further genetic heterogeneity at DFNA2. Acta Otolaryngol 2002;122 (7):730-5.

46) Tamagawa $Y$, Ishikawa K, Ishikawa K, Ishida T, Kitamura K, Makino S, et al. Phenotype of DFNA11: a nonsyndromic hearing loss caused by a myosin VIIA mutation. Laryngoscope 2002;112 (2):292-7.

47) Ishikawa K, Tamagawa Y, Takahashi K, Kimura H, Kusakari J, Hara A, et al. Nonsyndromic hearing loss caused by a mitochondrial T7511C mutation. Laryngoscope 2002;112 (8 Pt 1):1494-9.

48) Engel-Yeger B, Zaaroura S, Zlotogora J, Shalev S, Hujeirat Y, Carrasquillo M, et al. The effects of a connexin 26 muta-
tion--35delG--on oto-acoustic emissions and brainstem evoked potentials: homozygotes and carriers. Hear Res 2002; 163 (1-2):93-100.

49) Engel-Yeger B, Zaaroura S, Zlotogora J, Shalev S, Hujeirat Y, Carrasquillo M, et al. Otoacoustic emissions and brainstem evoked potentials in compound carriers of connexin 26 mutations. Hear Res 2003;175 (1-2):140-51.

50) Inoue Y, Kanzaki J, T OU, Ogawa K, Ogata A, Yoshihara S, et al. Clinical application of transiently evoked otoacoustic emissions after glycerol administration for diagnosis of sensorineural hearing loss. Auris Nasus Larynx 1997;24 (2): 143-9.

51) Guinan JJ Jr, Backus BC, Lilaonitkul W, Aharonson V. Medial olivocochlear efferent reflex in humans: otoacoustic emission (OAE) measurement issues and the advantages of stimulus frequency OAEs. J Assoc Res Otolaryngol 2003;4 (4):521-40

52) Abdala C, Ma E, Sininger YS. Maturation of medial efferent system function in humans. J Acoust Soc Am 1999; 105 (4):2392-402.

53) Moulin A, Collet L, Duclaux R. Contralateral auditory stimulation alters acoustic distortion products in humans. Hear Res 1993;65 (1-2):193-210.

54) Veuillet E, Collet L, Duclaux R. Effect of contralateral acoustic stimulation on active cochlear micromechanical properties in human subjects: dependence on stimulus variables. J Neurophysiol 1991;65 (3):724-35.

55) Williams DM, Brown AM. The effect of contralateral broadband noise on acoustic distortion products from the human ear. Hear Res 1997;104 (1-2):127-46.

56) Kim S, Frisina DR, Frisina RD. Effects of age on contralateral suppression of distortion product otoacoustic emissions in human listeners with normal hearing. Audiol Neurootol 2002;7 (6):348-57. 